\title{
Papers
}

\section{Do State pensions crowd out private saving? Evidence from the raised state pension age for British women}

Received: 10th October, 2000

\section{Richard Johnson}

was born in Oxford, England in 1973. He completed his PhD in Economics at Harvard in June 2000, and this paper was part of his thesis. He is now a research economist at the Federal Reserve Bank of Kansas City, having worked as an intern in the Fiscal Policy Department of the European Central Bank. His other interests include the economics of retirement behaviour, fiscal policy, and HIV/AIDS.

Keywords: saving; pensions; women; life-cycle theory; myopia; Ricardian Equivalence

\begin{abstract}
State pensions' effect on private saving and thus capital accumulation is disputed. This paper analyses the impact on saving of the rise in British women's State pension age from 60 to 65 using individual-level data. This change affects wealth but not work incentives. A raised women's pension age was expected before its announcement in November 1993, but which cohorts would be affected was not known. This paper compares saving by affected and unaffected cohorts of women, and that of men, before and after this announcement. No evidence is found of increased saving by women after the announcement. The conclusion is that younger women either were myopic in their saving behaviour or understood that their family dynasties' wealth was not affected by the reform.
\end{abstract}

\section{Introduction}

Whether unfunded pensions affect private saving is crucial to their evaluation and to predicting the effects of pension reforms. If state pensions are reduced, forward-looking individuals who are indifferent to taxes on their descendants will increase their saving. The author refers to such people as 'life-cycle' savers. 'Myopic' consumers, by contrast, will neglect to save more. Individuals who care about their children's lifetime consumption ('dynastic' savers) will realise that taxes on their descendants will fall together with state pensions. Reductions in their state pensions will leave their family dynasty no poorer, so they will not save more. Previous empirical work has failed definitively to establish which behaviour is most common. Many studies are subject to potentially severe methodological problems. In some reform cases, workers may not understand how their pension rights have changed. Omitted variables affecting saving may bias regression coefficients. More fundamentally, identifying precisely when savers realised their pensions would change in value is hard. The case of the rise in British women's state pension age 
has features allowing many of these methodological problems to be solved. Individual-level data from this period permit detailed examination and comparison of individual responses.

This paper examines the effect of the announcement on November 30th, 1993 that British women's state pension age would in the future rise from 60 to 65 . This will occur gradually from 2010 to 2020, so women born before 1950 will not be affected. There was no compensating change in pension levels. This announcement has several properties convenient for testing the effect of unfunded pensions on saving. First, only one system parameter changed, so the reform was easy to understand. Secondly, because the reform affected only some cohorts of women and no men, treatment and control groups can be identified. Comparisons of the differences in saving across the announcement for these groups control for omitted variables which were specific to either a time-period, cohort or sex. Thirdly, expectations about this reform can be reconstructed from contemporary newspapers. These show that, despite expectations of an increased women's pension age, there was little prior sense of which cohorts of women would lose pension rights. The sign of the difference in differences in saving under the life-cycle hypothesis can therefore be predicted without assuming the announcement was a negative surprise for young women or a positive surprise for older women, but only that it was one of these two. Fourth, state pensions in the UK are not income-tested, so the higher pension age is a pure wealth change. ${ }^{1}$ Unfortunately, it is impossible to tell how much specific women could expect to lose from the reform. Here a lower bound for women's losses is calculated as $3,500(\$ 5,256)$ in net present value in 1993.
This paper analyses savings behaviour using data from the General Household Survey (GHS), the British Household Panel Survey (BHPS) and the Family Expenditure Survey (FES). The GHS is a yearly cross-sectional survey which asks respondents about their participation in occupational and personal pensions. The BHPS permits examination of a fixed group of people through time, and asks respondents the binary question 'Do you save?', about private pension membership, and about dividend and interest income. The FES is another yearly cross-section, and includes information on bond and equity ownership and holdings of Tax-Exempt Special Savings Accounts (TESSAs). Saving rates can be constructed from the income and expenditure data in the FES, but vary so widely across households that learning much from them is difficult. Therefore the author concentrates here on binary variables which give a rough characterisation of saving behaviour.

Analysis of these data shows no evidence that the pension age announcement affected women's saving. Saving by men was also stable across the announcement, so husbands do not appear to have responded to their wives' smaller pensions. Women's participation in occupational and personal pensions was fairly static across the 1990s, and no step changes in behaviour are evident after 1993. Responses to the question 'Do you save?', and equity, bond and TESSA ownership were similarly constant. Young people tracked through time in the BHPS became significantly more likely to have dividend and interest income. However, this appears a consequence of increasing age rather than an effect of the 1993 announcement, as young people in the FES hold no more bonds or equity over time. Thus no support was found for the life-cycle theory; women appeared to have been either myopic or conversely 
sophisticated, dynastic consumers. The power of this test depends on how large are the regression standard errors compared to the behavioural response we would expect under the life-cycle hypothesis. It is not possible to construct likely behavioural responses in binary variables such as pension participation, but simple calculations imply saving by young households would have increased by around 1 per cent of income, suggesting small changes in binary variables. Thus this paper presents a fairly weak test of state pensions' effect on saving.

This paper is organised as follows. The next section explains different theories of unfunded state pensions' effects on private saving. After this, there is a section which surveys previous empirical approaches to this question and the identification problems they face. The next part describes state and private pensions in the UK, and trends in pension markets which could bias my regressions. After this, the paper details the reform announced in November 1993 and the timing of information-release about it. The next section discusses the GHS, BHPS and FES data used. Following this, the next part describes the empirical methods employed and their results. The conclusion discusses how policy might respond to a lack of foresight in saving. Appendices show the reform announcement and how the BHPS data were manipulated.

\section{Theories of the effect of unfunded pensions on saving}

State pension systems compel contributions from workers and make payments to the old. Though most have reserves of assets, these are typically small relative to the pensions promised to present and former contributors; promised pensions could not be funded from the reserve of assets. Therefore pensions are largely paid directly from workers' contributions, so the systems are 'unfunded' and enforce transfer payments from workers to the old. Three theories predict different reactions by the young to information about the value of the transfers they will eventually receive.

The 'myopia' theory assumes workers make no long-term plans for their consumption. Having no programme for financing their old age, such young people would not save more on learning that their state pensions would be smaller than they had hitherto thought.

Functioning humans need some ability to anticipate the future, so myopia is hard to sustain as a general model of human behaviour, but nevertheless has some plausibility as a description of retirement saving. If all workers are myopic, then information about the future cannot change private saving or capital accumulation today.

The 'life-cycle' theory assumes more sophistication on workers' part. 'Life-cycle' consumers use all available information to plan their consumption over their remaining lifespans. They do not consider the utility of their descendants when making these plans, due either to indifference to their descendants' happiness or an inability to think about events beyond their own deaths. Predicting 'life-cycle' consumers' response to pension reforms can be difficult, given the complexity of pension systems. However, the lack of income or asset testing of British state pensions means the 1993 announcement changed wealth but not prices. Therefore, with weak restrictions on preferences, it is possible to state that female life-cycle consumers would have increased their saving in response.

The logic for this prediction is as follows. Assume agents gain utility from both consumption and leisure in every 
period they live. They can forgo leisure by working, thereby earning $\mathrm{w}$ pounds per hour. If we assume agents' marginal utility from leisure increases predictably with age, they will plan for a

'retirement' period and save during their youths to maintain consumption in it. Besides wages, agents are endowed with assets A which include the value of all transfers, net of taxes, they expect to receive from the government. The 1993 announcement represented a fall in women's levels of A. Its implications for market prices were minimal. ${ }^{2}$ If we assume consumption and leisure in all periods are normal goods, the demand for which rise with wealth, lower A induces lower consumption and less leisure in every period. For a fixed wage $\mathrm{w}$, young agents will supply more labour, earn more, consume less, and thereby save more. They will also retire later, but this does not alter the conclusion that their saving when young will increase. For leisure and consumption in all periods to be normal goods is a restriction on agents' utility functions, but a natural one. All utility functions which are separable in their arguments imply normal demands for each good, for example. As a counter-example, if we simplify to two-period lives consisting of youth and old age and ascribe to life-cycle consumers the following (inseparable) quasi-linear utility function,

$$
U=c_{1}^{\alpha} L_{1}^{\beta} L_{2}^{\chi}+c_{2}
$$

where $L$ is leisure, $c$ consumption, and the subscripts denote periods, then changes in A will only affect consumption when old, $c_{2}$. With this utility function we return to the predictions of the myopic model from within the life-cycle framework.

Restricting ourselves to more plausible utility functions, however, implies young women would have saved more after the 1993 announcement.
The dynastic model of consumption, as set out by Barro, ${ }^{3}$ assumes agents gain utility both from their own lives and from their children's lifetime utilities. If each generation cares about the utility of the next, effectively each agent maximises the utility of her entire future dynasty. Such 'dynastic' agents will care about both the transfers they receive in their old age and taxes on their descendants. The 1993 budget speech (Appendix A) stated that savings from the raised female pension age would result in lower taxes on workers in the 21 st century. Therefore, the typical 'dynastic' worker should have interpreted the reform announcement as having no effect on her future dynasty's available resources, and not changed her saving in response. This 'social security neutrality' result is similar to the 'debt neutrality' implication of the dynastic theory; in both cases transfer between generations enforced by governments have no effect on consumption.

There may be 'myopes', 'life-cycle' and 'dynastic' consumers in the same population. Empirical study must tell which behaviour predominates. It should be noted that any saving behaviour can be justified ex post as fitting within either the life-cycle or dynastic model if a suitable set of ex ante expectations are assumed. For example, had life-cycle consumers expected every detail of the 1993 announcement long before, their saving would not have been changed by it. Therefore empirical study of this question must test joint hypotheses about behaviour and expectations.

\section{Previous empirical work on unfunded pensions' effect on saving}

Empirical tests of the life-cycle theory have used three general approaches. The first, employed by Feldstein ${ }^{4,5}$ and subsequent authors including Barro, ${ }^{3}$ 
Leimer and Lesnoy ${ }^{6}$ and Meguire, ${ }^{7}$ uses time-series variation. Aggregate national consumption is regressed on aggregate disposable income, controls and a 'Social Security Wealth' (SSW) variable intended to capture workers' expectations of their state pensions. However, Social Security Wealth series are typically constructed from legislative or payment histories with little explicit attention to expectations. For example, Feldstein's SSW series, ${ }^{5}$ in billions of 1987 US dollars, jumps from 0 to 448.1 from 1936 to 1937 and from 4,916.1 to 6,197 from 1971 to 1972 . Such jumps implicitly assume the Social Security laws of 1937 and 1972 were not expected beforehand. This may be true, but since expectations are crucial to establishing the variance of SSW scientific method probably requires more evidence for this assumption. These time-series approaches are also subject to many potential omitted variable biases, as variables such as the value of promises of state medical spending are excluded. Probably due to these two criticisms, Feldstein's ${ }^{5}$ finding that 1992 US Social Security Wealth of about $\$ 14$ trn reduced US saving in that year by around $\$ 420$ bn, or by about half, remains controversial.

A second approach examines cross-country variance in saving rates and state pensions. Here high measured saving in Germany and Italy, which have large state pensions, and low saving in the UK, which has meagre state pensions, appear to contradict the life-cycle hypothesis. Private saving is, however, difficult to compare across countries and many relevant variables, such as the sophistication of national mortgage markets, are hard to measure, so this approach is also problematic. Feldstein ${ }^{8}$ finds significant crowding-out of private saving by state pensions in a cross-section of countries. In contrast to international studies, cross sections of individuals within one pension system cannot distinguish between the life-cycle and dynastic theories, since each predicts a negative cross-sectional relationship between state pension rights and individuals' saving. Cross-sections of individuals can, however, rule out the myopia theory, since this predicts no relationship between state pensions and saving of any kind.

A third method combines cross-section and time-series variation in state pension guarantees. Edwards ${ }^{9}$ analyses a panel of 36 countries from 1970 to 1992, which enables some omitted variable biases to be removed by country and time effects. Identification of life-cycle saving behaviour is once more dependent on time-variation of pension expectations, but again Edwards' treatment of expectations is crude. His state pension variable, the ratio of social security payments to total government spending, would entirely fail to capture legislative events with delayed benefit implications. Edwards finds significant negative effects of state pensions on national saving.

In summary, the combination of cross-section and time-series data on state pension wealth and saving has advantages in reducing omitted-variable biases. The difficulty of modelling expectations remains. Bernheim and Levin ${ }^{10}$ note that the US Retirement History Survey asked in 1969, 1971 and 1973 for the level of Social Security benefits respondents expected upon retirement. Panel data on expected benefits would be the ideal right-hand-side data to test the life-cycle theory. Without such data, the present paper analyses a reform in which a wide range of prior expectations would imply the same sign of the difference-in-difference of saving.

\section{Private and State pensions in the UK}

The context of the 1993 reform was a small but near-universal flat-rate state 
Table 1 Percent of UK labour force contributing to private pensions in 1998

\begin{tabular}{llll}
\hline & $\begin{array}{l}\text { Occupational } \\
\text { pension }\end{array}$ & $\begin{array}{l}\text { Personal } \\
\text { pension }\end{array}$ & $\begin{array}{l}\text { Any private } \\
\text { pension }\end{array}$ \\
\hline Men working full time & 57 & 25 & 72 \\
Women working full time & 56 & 15 & 64 \\
Women working part time & 27 & 9 & 34 \\
\hline
\end{tabular}

Note: In 199839 per cent of working-age women worked full time, 21 per cent worked part time and 6 per cent were unemployed. Source: General Household Survey for 1998.

Basic Pension and an optional State Earnings-Related Pension Scheme (SERPS). ${ }^{11}$ In the private sector, employer-sponsored pension plans, which typically promise defined benefits, covered a majority of full-time employees and, since 1986, financial institutions had sold many 'personal pensions', generally defining a contribution only, to individual savers. This section describes the British private pension market and changes to it which could bias the regressions below. It then discusses state pensions in more detail. Pension reforms by the Labour government since 1997 do not affect the analysis of events in the early 1990s, but are relevant to the policy recommendations in my conclusion.

\section{Private pensions}

Table 1 lists the percentages of the UK labour force who were members of private pension schemes in 1998. Around half of all workers belonged to occupational pension schemes. The third row shows that women working part time were least likely to participate in either employer-sponsored or personal pensions. Those working part time or in small firms are least likely to be offered occupational pensions by their employers. An attraction of occupational pensions and, since 1988, of personal pensions is that contributors may leave SERPS, thereby receiving 'rebates' from the government against their payroll taxes.
Workers cannot leave the state Basic Pension, however.

\section{Changes in private pensions during the 1990s}

The regressions below associate changes in saving behaviour over time with responses to the 1993 reform. Many omitted variables, such as trends in house prices and personal taxation, might also affect saving. The comparisons of differences below mean omitted variables will not bias the regressions if they were equal at a given time either for all women or for all people of a certain age. There may be more general omitted variables, however. Three developments in the UK pension markets in the early 1990s appear most relevant to saving and pension participation decisions: the equalisation of pension ages within occupational pension schemes, the time-pattern of government 'rebates' for opting out of SERPS, and the 'scandal' surrounding the mis-selling of personal pensions.

In the 1980s most British occupational pension schemes paid women pensions at younger ages than they did men. The European Court of Justice ruled this practice illegal on 17th May, 1990 in its decision in Barber v. Guardian Royal Exchange. Most firms then raised pensionable ages for women to the pre-existing age for men. This might appear to have reduced many women's pension wealth substantially. However, 
barring rigidities in labour markets, changes to firms' costs of providing pensions to female workers for current labour will be exactly offset by changes in women's wages. Thus only reductions in pension rights earned by past labour should reduce female workers' wealth. The Barber decision only requires firms to equalise pensionable ages in respect of labour provided after 17th May, 1990, so it probably had little effect on women's pension wealth. ${ }^{12}$

Government policy raised incentives to take up private pensions between 1988 and 1993. Since April 1988 workers have been permitted to leave SERPS if they contribute to personal private pensions with certain minimum features. An extra rebate against payroll taxes for those newly opting out of SERPS and into either a personal or occupational pension was offered for the five years to April 1993. This 'incentive' rebate featured heavily in advertising by private pension providers, and by $19904 \mathrm{~m}$ qualifying personal pensions had been sold. ${ }^{13}$ SERPS favours women, as its benefit structure takes no account of women's lower death rates. Thus the 'incentive' rebate was particularly relevant to young men. We would expect a decline in private-pension take-up by young men after 1993, making young women look relatively as though they moved into private pensions after this date. A bias in favour of observing a 'life-cycle' effect is thus created in comparisons between the sexes. No life-cycle effect is observed, however, so there is not have a 'false positive' result.

The 'pensions mis-selling scandal' may induce more complicated biases. From 1993 onwards, newspapers and a report commissioned by the Financial Services Authority found that thousands of employees had been wrongly advised to leave their occupational pensions in favour of personal pensions. Much negative publicity for personal pensions ensued. Since private pensions are more attractive to men, as explained above, the 'scandal' is likely to have affected particularly male participation in personal and occupational schemes. Declining male participation in personal pensions after 1993 would, as above, bias the triple difference in participation toward the life-cycle sign. Increased male participation in occupational pensions after 1993 would induce the opposite bias in this triple difference, towards a 'false negative'. In fact, men made little or no movement into occupational pensions after 1993, so it does not appear that bias due to the 'scandal' means the negative result of my comparison of occupational pension membership rates is in fact false.

\section{State payments to the old in the UK}

The UK government pays flat-rate Basic Pensions and the State Earnings-Related Pension (SERPS) to qualified people over the state pension age. ${ }^{14}$ In 1940 the pension age for women was reduced to 60 , while that for men remained 65. Several income and asset-tested benefits are available to all people, including the old. Receipt of state pensions is not conditioned on earnings or asset income, so all changes in their levels have pure wealth effects. ${ }^{15,16}$ The rate of Basic Pension for a claimant with the full number of contributory years was, in 1997, £62.45 per week. Spouses with no contribution histories could claim Basic Pensions of 60 per cent of this, or £37.35 per week. Since 1980 these rates have been increased each year in line with inflation, not earnings. SERPS pays an additional 20 per cent of average lifetime earnings. ${ }^{17}$ However, from SERPS' inception in 1978, 
Table 2 Mean weekly incomes of 'recently retired' pensioner households in 1996/7, July $1996 £$ per week. Bracketed figures: Proportion in receipt of each benefit

\begin{tabular}{lcc} 
& Pensioner couples & Single pensioners \\
\hline Gross income: & 348 & 182 \\
Benefit income, of which & 127 & 89 \\
State pension & 108 & 63 \\
& $(97)$ & $(90)$ \\
Income-related benefits & 9 & 17.1 \\
Disability benefit & $(27)$ & $(38)$ \\
& 9 & 6.9 \\
Occupational pension & $(18)$ & $(16)$ \\
Investment income & 102 & 43 \\
Earnings & 55 & 16 \\
Other income & 63 & 31 \\
Net income before housing costs & 2 & 3 \\
$\quad$ Mean & 297 & 155 \\
Median & 240 & 129 \\
\hline
\end{tabular}

Note: The 'recently retired' are defined to be single men aged 65-9, single women aged 6--4, and couples in which the man is aged 65-9. The categories of state benefits do not add to the total due to rounding errors. Source: Social Security Statistics, (1999).

employer-sponsored pension schemes could 'contract-out' of it, receiving in return rebates against members' payroll taxes. In 198788 percent of occupational-pension contributors belonged to schemes which had left SERPS. ${ }^{16}$ Since 1988 workers contributing to approved personal pensions have also been able to leave SERPS. The participation rates in private pensions listed in Table 1 imply that SERPS covers a minority of workers.

The importance of the state pension in retirees' incomes will fall by cohort. Average earnings grow faster than inflation, and thus Basic Pensions, and the spread of private pensions generates other sources of retirement income. Table 2 breaks down by source the average incomes of 'recently-retired' single pensioners and pensioner couples in 1996/7. 'Recently-retired' pensioners comprise single women aged 60-4, single men aged 65-9, and couples in which the man is aged 65-9. The figures in brackets are the percentages in receipt of each benefit; 97 per cent of recently-retired pensioner couples received some state pension. The average, including zeros, of both Basic and SERPS pensions was 108 per week for such couples, or 31 per cent of gross income. Ninety per cent of young single pensioners received a state pension, with the average including zeros 63 per week or 35 per cent of gross income.

\section{Eligibility criteria for the basic pension}

In theory, rights to Basic Pensions are earned by the payment of National Insurance Contributions (NICs), or payroll tax. Men become eligible for the full Basic Pension by paying NICs above a minimum level for 44 years. Women require 39 contributory years for a full pension until 2010, rising to 44 years by 2020. The pension is reduced proportionately if contributions were made for fewer years. A married woman receives the higher of the spousal benefit and that generated by her own contributions. Widows receive the higher of the pensions generated by their own contributions and 100 per cent of that generated by their deceased husbands'. 
Table 3 Net present value of loss in 1993 from increased female pension age, 1993 currency units. (Loss from delayed basic pension only)

\begin{tabular}{|c|c|c|c|c|c|c|c|c|}
\hline \multirow{3}{*}{$\begin{array}{l}\text { Woman born } \\
\text { in March of } \\
\text { year }\end{array}$} & \multirow{3}{*}{$\begin{array}{l}\text { Age in } \\
1993\end{array}$} & \multirow{3}{*}{$\begin{array}{l}\text { Years of } \\
\text { pension } \\
\text { lost }\end{array}$} & \multicolumn{5}{|c|}{ Discount rate (\%) } & \multirow{3}{*}{$\begin{array}{l}7 \\
£\end{array}$} \\
\hline & & & 3 & 4 & 5 & 5 & 6 & \\
\hline & & & $\boldsymbol{\varepsilon}$ & $£$ & 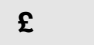 & $\$$ & $£$ & \\
\hline 1968 & 25 & 5 & 3,406 & 2,502 & 1,843 & 2,768 & 1,362 & 1,010 \\
\hline 1963 & 30 & 5 & 3,948 & 3,043 & 2,352 & 3,532 & 1,823 & 1,417 \\
\hline 1958 & 35 & 5 & 4,577 & 3,703 & 3,002 & 4,508 & 2,440 & 1,987 \\
\hline 1955 & 38 & 5 & 5,001 & 4,165 & 3,476 & 5,219 & 2,906 & 2,434 \\
\hline 1953 & 40 & 2 & 3,089 & 2,596 & 2,186 & 3,283 & 1,844 & 1,558 \\
\hline 1951 & 42 & 1 & 999 & 832 & 693 & 1,041 & 579 & 484 \\
\hline $\begin{array}{l}1950 \text { or } \\
\text { earlier }\end{array}$ & 43 plus & 0 & 0 & 0 & 0 & 0 & 0 & 0 \\
\hline
\end{tabular}

Note: $£ 1=\$ 1.5016$ on average in 1993 according to the 1994 Economic Report of the President. Calculations assume women would be eligible for a full spousal benefit. Women with full contribution histories would lose 167 per cent of these figures. Never-married women without pension rights would receive means-tested income support before and after the reform and thus lose nothing. The figures quoted are pre-tax losses.

In fact, since 1978 pensioners have been forgiven years of non-contribution for several reasons. Years of registered unemployment, disability, caring for children younger than 16 or for elderly or disabled people can substitute for years of contribution. In 199495 per cent of male pensioners received the full Basic Pension. In 1994 only 27 per cent of women received a full pension on the basis of their own contributions.

Projections for 2010 are that greater labour force participation and the relaxed eligibility criteria will make 66 per cent of married women eligible from their own contributions for a pension larger than the spousal benefit. ${ }^{17}$

None of the data sets used here contain workers' contribution histories. Indeed, to estimate whether women younger than 65 would receive full Basic Pensions or the spousal benefit would require forward projections of their earnings. There is no information about individuals' membership of SERPS either. Marital status could affect pension wealth because single women cannot claim spousal benefits. The author assumes a typical pension loss for each cohort of women, and use marital status as a control variable.

\section{The increased State pension age for women in the UK}

The 1995 Pensions Act, as first announced in 1993, will raise the female pension age to 65 in steps between 2010 and 2020. Women born before April 6th, 1950 remain eligible for a state pension from the age of 60 . Those born between April 6th, 1950 and April 5th, 1955 may draw a state pension from the age of 60 plus one month for every month or part thereof they were born after April 5th, 1950. Women born after April 5th, 1955 must wait until age 65 before drawing a state pension. The Act did not alter state pensions for men.

Table 3 lists the net present value in 1999 currency units of women's losses from the 1993 budget, for a range of discount rates. Since the Basic Pension is indexed to inflation, this paper assumes its real value will remain constant. Here women are assumed to expect the full spousal benefit under the Basic Pension but no State Earnings-Related Pension. Thus this table gives for most women a lower bound to the net present value of their losses from the higher pension age. It can be seen that women aged 43 or more in 1993 lose nothing from the reform, as their pensions will still be paid 
from age 60 . Women aged 37 or 38 in 1993 lose over $\mathcal{E}^{3}, 000$ from the reform using a constant discount rate of 5 per cent. The 'wealth surprise' created by the 1993 announcement depends on expectations prior to it. Had the entirety of the announcement been anticipated beforehand, the losses in Table 3 would not have affected saving even under the life-cycle hypothesis, as they would already have informed workers' consumption plans. To establish what wealth surprises obtained, it is necessary to examine information about the reform prior to its announcement.

\section{Expectations before the announcement}

Contemporary sources give a sense of expectations of government pension policy in 1992 and 1993. The then Chancellor of the Exchequer (Finance Minister) Kenneth Clarke announced the government's plan to raise the female pension age in his presentation of the new budget to parliament on November 30th, 1993. ${ }^{18}$ The government had previously committed to equalising state pension ages, but not to a specific equalised age. ${ }^{19}$ The Social Security Advisory Committee's report to the government, published in 1992,13 discussed proposals to equalise pension ages at 60 . It then advised equalisation at 65 , with the female pension age raised in steps between 2000 and 2015. Under this proposal, all women born after 1940 would have lost some pension rights. If the Advisory Committee report formed expectations before the 1993 budget speech, the latter contained only the information that women born between 1940 and 1950 had kept their pension rights and that women born between 1950 and 1955 had lost less than had been recommended.

Shortly before each new budget,
British newspapers forecast its contents, with increasing accuracy close to the speech as government ministers leak details to journalists in unattributable briefings. An article in The Times on November 22nd commented:

'At least the Treasury should have no truck with plans to raise women's retirement age to $65 \ldots . .^{22}$

suggesting doubt as to whether any reform would happen. On November 27th The Guardian wrote:

'The ... statement signalling the Government's intention to raise the pension age for women to 65 is also likely in the Budget. The measure ... is likely to affect only women under $40 .^{, 22}$

This mistook the inter-cohort effect of the reform slightly, since women aged 42 would lose some pension. The day before the budget speech, The Times stated:

\footnotetext{
'An announcement that the government has decided to raise the retirement age for women from 60 to 65 will also come this week ... The change ... will not affect women approaching retirement age. However, it will mean that women below their mid-40s will have to wait an extra five years for their pension. ${ }^{, 23}$
}

This was again incorrect, as only women then aged 38 or less would have to wait fully five years longer for state pensions. The difference-in-differences approach used below assumes the 1993 budget contained information either differentially good for older female cohorts, differentially bad for younger female cohorts, or both. The sign of the differential saving response in the life-cycle model can be predicted without judging which group was surprised, only that at least one was. 
Women may well have expected an increase in their state pension age to 65 in 1992-3. However, since even the day before the budget, journalists could not predict the effects of the reform on different cohorts of women, it can be safely assumed most women could not have done so either.

\section{Awareness of the reform after its announcement}

In the UK, government-sponsored acts rarely fail to become law. The details of budget speeches are also published in newspapers, so women need have been in little doubt about future state pension ages beyond December 1st, 1993. Yet they might have remained ignorant. Britain's highest-circulation newspaper, the down-market Sun, covered the budget at length on December 1st but contained only one line about the pension-age change, 'Increasing the retirement age of women to age 65'. That day's Sun and Daily Mirror, the second-largest circulation newspaper, each contained several case studies of the budget's effect on different families, summarising each with a per-week gain or loss figure. Where the studied families contained young women, no mention was made of their lost pension rights, and the calculated loss did not include it, perhaps because this was hard to translate into a current weekly equivalent. This pension reform did not become politically contentious, probably because it was introduced as 'ending discrimination'. Private pension providers did not launch campaigns targeting women after the announcement. ${ }^{24}$ Therefore some ignorance of the reform's detail is plausible. We could think of ignorance as an alternative to the 'myopia' theory, or combine the two, re-defining 'myopia' as not acting on, or not collecting information relevant to, lifetime resources. If so, 'life-cycle' theory tested includes an assumption about collecting relevant information as well as one about preferences.

\section{The wealth surprise of the increased female pension age}

Translating the losses in Table 3 into a 'wealth surprise' of the 1993 announcement depends rather subtly on the prior state of expectation assumed. The author now sketches the cohort-specific net-present value 'wealth-surprise' of the announcement under three expectational scenarios. It is assumed all women had the same prior expectations, a constant real discount rate of 5 per cent and were risk-neutral.

Case 1: With certainty, the pension age was expected to be raised from 60 to 65 phased in gradually from 2000 to 2015, rather than the actual 2010 to 2020. The only positive wealth surprises would have been positive ones for older women, peaking at $£ 3,832$ for women born in April 1950.

Case 2: With certainty, the pension age was expected to be raised gradually from 60 to 65 from 2020 to 2030. Here the only wealth surprises would have been the negative ones for women born between 1950 and 1960 shown in the relevant rows of Table 3 , peaking at f3,476 for women born in 1955.

Case 3: There was a 50 per cent expectation of no change at all, and a 50 per cent expectation of a gradual rise from 60 to 65 between 2000 and 2010 . The peak positive wealth surprise is $£ 1,465$ for women born in 1945 , and the most negative surprise is $\mathcal{E} 1,738$ for women born in 1955.

Case 1 is that recommended by the Advisory Committee Report of 1992. Other expectations might have obtained, 
perhaps entirely accurate ones, in which case there were no wealth surprises at all. The three cases above show, however, that under a fairly wide range of hypotheses, the 1993 announcement contained information that was differentially bad for younger women by about $£ 3,500$ in net present value.

A simple simulation exercise helps construct the predicted saving response to this reform under the life-cycle model. The author proceeds with expectational Case 2 above, wherein younger women felt poorer following the announcement. The median normal disposable income of all married couples in the 1993-4 FES was $\mathcal{E}^{3} 30$ per week or $\mathcal{E} 16,619$ per year. Median disposable income of couples where the wife was aged from 28 to 38 was slightly higher, at $£ 336$ per week or $£ 17,449$ per year. To offset a loss with net present value $K$ during the next 25 years, a woman aged 35 in 1993 and her husband would have to increase their saving rate by $s$, where

$$
\begin{aligned}
& s I(1+r)^{25}+s I(1+g)(1+r)^{24} \\
& +\ldots+s I(1+g)^{25}=K(1+r)^{25}
\end{aligned}
$$

$I$ is income, $r$ the real interest or discount rate, and $g$ the real growth rate of wages. The assumption of constant earnings growth is simplistic but gives a rough measure of plausible saving responses. Equation (2) implicitly defines $s$ as a function of $K$ for given $I, g$, and $r$. Setting $\mathrm{I}=17,000, r=0.05$ and $K$ as 3,476 , the net present value of the loss assuming a 5 per cent discount rate, from Table 3, we have

$$
\begin{array}{lllll}
g & 0 & 0.01 & 0.02 & 0.03 \\
s & 0.012 & 0.011 & 0.01 & 0.09
\end{array}
$$

Thus the median married couple in the relevant cohort needed to save around one extra per centage point of income to have assets on the wife's 60th birthday equal to the pension rights she lost from the 1993 reform. This small figure reflects that consistent saving with even a low compounded interest rate generates considerable assets after 25 years. The losses in Table 3 reflect the assumption that wives would lose claims to dependants' benefits only. Were they to lose rights to full-rate benefits, the $\mathrm{s}$ figures above would be multiplied by 1.67 and the off-setting increase in saving would be between 1.6 and 2.2 per centage points. We would expect, however, that couples would also respond to lower pension wealth by increasing their labour supply and lowering their total wealth target at age 60 , implying that saving rate responses could have been even lower than 1 per cent.

Greater earnings and higher saving rates would imply a larger volume of saving, which should be reflected in binary variables such as participation rates in private pensions and ownership of equity.

\section{Data}

\section{The General Household Survey}

The General Household Survey (GHS) has been conducted by the UK Office for National Statistics every year since 1971. It questions people aged 16 or more in each of about 9,000 randomly-selected households each year, and includes questions about private pension participation. Unfortunately, until 1996 the proportion of the population with 'Any private pension' was calculated by adding the proportions with occupational and personal pensions, ignoring the overlaps evident in Table 1. The 1996-7 survey, the most recent for which results are available, questioned about 17,000 adults or about 0.4 per cent of those in the entire UK. Here the 
author use not raw GHS data but rather aggregated results published annually in volumes entitled Living in Britain.

\section{The British Household Panel Survey}

The British Household Panel Survey

(BHPS) has interviewed every adult member of around 5,000 households, or about 10,000 people, yearly since 1991 . It is best used as a panel of individuals, since marriage, divorce and death make household variables difficult to compare across time. The survey's conductors attempt to maintain the survey's panel nature by re-interviewing every sample member in subsequent years. There are, nevertheless, many 'leavers' and 'joiners'. Three BHPS questions are useful in the present context: 'Do you save?', 'Do you contribute to a Personal Pension?', and 'How much dividend or interest income did you have last year?'. ${ }^{25}$ All people who missed or failed to answer relevant questions in any of the eight survey waves were dropped. The author thereby examines exactly the same people over time, so any apparent behavioural changes are genuine, rather than a result of differing samples each year. This remaining BHPS sample may not be representative of the British population; for example older and poorer people are more likely to die between waves and thus be excluded entirely.

The BHPS conducts 96 per cent of its interviews from August to the end of November. Difficulties in contacting some people delay a very small number of interviews as late as May the following year. Such individuals may therefore be interviewed no times in one calendar year but twice in the next. The author has recoded interviews in January to May of any year as having taken place the year before, and therefore observe exactly the same sample of people in each re-defined year. This re-coding of interview dates slightly confuses the interpretation of the year effects, but extinguishes error due to differing samples within each year. We can get rid of one of these two types of error but not both.

\section{The Family Expenditure Survey}

The Family Expenditure Survey (FES), like the GHS, surveys a new random sample of households each year. Comparison of household-level variables makes more sense in the FES since, for example, childless couples can be compared over time without worrying that specific couples have since had children. The FES asks about ownership rates of various financial instruments including personal pensions, Tax-Exempt Special Saving Accounts, and 'Stocks, shares etc.' which includes both equity and bonds. This paper discusses results from the FES very briefly, as they replicate those found using the GHS and BHPS.

\section{Methods and results: Empirical approach}

Comparing the group mean saving behaviour of female 'pension losers' and 'pension retainers' both before and after the 1993 announcement constructs a 'difference-in-difference' test of the life-cycle hypothesis. In this case, older women are considered a control group. The validity of using men as another 'untreated' control group is arguable. Men were not directly affected by the reform but could have responded to the losses of their present or future wives. The use of men as another control group produces a 'difference-in-differencein-differences' test. Comparisons of group means may be generalised to the inclusion of other control variables. 
Table 4 Participation rates in occupational and personal pensions, from the General Household Survey

\begin{tabular}{|c|c|c|c|c|c|c|c|c|c|}
\hline \multirow[b]{3}{*}{ Year } & \multicolumn{9}{|c|}{ Percent participating in occupational pensions } \\
\hline & & \multirow{2}{*}{$\begin{array}{l}\text { Men working } \\
\text { full time } \\
\text { Aged } \\
25-34\end{array}$} & & \multicolumn{3}{|c|}{$\begin{array}{l}\text { Women working } \\
\text { full time }\end{array}$} & \multicolumn{3}{|c|}{$\begin{array}{c}\text { Women working } \\
\text { part time }\end{array}$} \\
\hline & All & & $\begin{array}{l}\text { Aged } \\
45-54\end{array}$ & All & $\begin{array}{l}\text { Aged } \\
25-34\end{array}$ & $\begin{array}{l}\text { Aged } \\
45-54\end{array}$ & All & $\begin{array}{l}\text { Aged } \\
25-34\end{array}$ & $\begin{array}{l}\text { Aged } \\
45-54\end{array}$ \\
\hline 1991 & 61 & 58 & 73 & 55 & 60 & 64 & 17 & 17 & 23 \\
\hline 1992 & 62 & 56 & 70 & 54 & 57 & 67 & 19 & 19 & 24 \\
\hline 1993 & 60 & 55 & 73 & 54 & 56 & 63 & 19 & 20 & 22 \\
\hline 1994 & 60 & 55 & 72 & 53 & 53 & 62 & 19 & 23 & 22 \\
\hline 1995 & 58 & 53 & 70 & 55 & 57 & 61 & 24 & 24 & 29 \\
\hline 1996 & 58 & 53 & 71 & 53 & 56 & 61 & 26 & 25 & 31 \\
\hline \multirow[t]{2}{*}{1998} & 57 & 54 & 69 & 56 & 58 & 64 & 27 & 29 & 31 \\
\hline & \multicolumn{9}{|c|}{ Percent contributing to personal pensions } \\
\hline 1991 & 26 & 25 & 25 & 19 & 17 & 23 & 11 & 10 & 14 \\
\hline 1992 & 27 & 33 & 26 & 21 & 20 & 22 & 12 & 12 & 15 \\
\hline 1993 & 29 & 38 & 26 & 22 & 27 & 17 & 12 & 12 & 17 \\
\hline 1994 & 28 & 36 & 25 & 20 & 24 & 18 & 11 & 12 & 13 \\
\hline 1995 & 28 & 37 & 28 & 22 & 26 & 22 & 11 & 14 & 13 \\
\hline 1996 & 26 & 35 & 23 & 18 & 24 & 15 & 9 & 15 & 12 \\
\hline 1998 & 25 & 31 & 24 & 15 & 20 & 14 & 9 & 16 & 8 \\
\hline
\end{tabular}

Note: There was no GHS in 1997.

However, because age is determined by birth, cohort and time, it is possible to control for any two of time, cohort and age but not all three simultaneously.

\section{GHS evidence on private pension membership}

Table 4 shows trends in private pension participation during the 1990s. We could turn these numbers into formal

difference-in-difference estimates, but the simple trends give an intuitive sense of the data. The table reports participation rates in occupational and personal pensions in the 25 to 34 and 45 to 54 age groups of both men and women, taken from the GHS summary volume Living in Britain. In each year, women aged 25 to 34 are 'pension losers' who lost five years of pension in the 1993 reform. Until 1995, the 45 to 54 year-old female age group contained only women who lost nothing from the 1993 reform. By 1998, the last GHS currently available, women aged 45 had lost up to three years and eight months of pension. Women aged 49 or more would still have lost nothing. Therefore the 45 to 54 age group largely corresponds to 'pension retainers', though a minority of 'pension losers' are present by 1998 .

The upper panel of Table 4 shows participation rates of working men and women in employer-sponsored pensions. The author distinguishes between full and part-time women workers, because their likelihood of belonging to an occupational pension is very different. Very few men work part time. The first three columns show slightly falling membership of occupational pensions among both younger and older men during the 1990s. In columns four to six it is shown that participation of women working full time dipped and then recovered during the decade. This pattern is plausibly due to the heavy advertisement of personal pensions prior to 1993 and the negative publicity they attracted thereafter. No particular rush 
into occupational pensions by young women after 1993 is evident. Columns seven to nine show a gradual increase in participation by both young, 'pension-losing' and older, 'pension-retaining' female part-time workers. From 1993 to 1998 there are nine percentage point increases among both age groups, so again young women were not disproportionate joiners.

Table 4's lower panel shows the proportion of workers contributing to personal pensions. Here columns two and three show this proportion rise and then fall among both ages of men, consistent with the government's 'incentive rebate' offer from 1988 to 1993 and the personal pensions 'scandal' after 1993. Column five shows young full-time women workers moving strongly into and then out of personal pensions. Older women, in column six, generally moved out of them. A life-cycle saving effect in this context might be steady participation in personal pensions by young women while older women and men left them; this is not what we see in column five. We do see this, though, in columns eight and nine of the lower panel. Over the 1990s, women working part time moved slowly into personal pensions; older women moved away from them after 1993. Column eight shows no step change in pension contributions by younger women directly after 1993, however, so it is not clear that we are observing an effect of that year's 'wealth surprise'. Overall the group proportions in Table 4 exhibit little sign of a differential response to the pension age announcement.

Besides variables changing across time, such as the government's 'incentive rebate' offer, individual-specific variables could also create misleading trends. For example, saving tends to rise with education levels, so were the GHS to sample more educated people in a given year, observed pension participation rates would probably rise. All variables fixed by individual will be held fixed by observing the same sample of people through time, which we can do using the BHPS.

\section{Summary statistics from the 1998 BHPS}

After deletions for missing data, 5,563 individuals from the BHPS remain, each interviewed in each of the eight waves from 1991 to 1998. This sample is divided into eight cells by sex and birthdate. ${ }^{26}$ Respondents born before 1932 are labelled 'Very Old'; those born between 1932 and 1949 'Old', those born from 1950 to 1955 'Middle-aged', and those born from 1956 to 1976 'Young'. 'Old' women did not lose pension rights as a result of the higher pension age. 'Middle-aged' women lost from one to five years of pension, and 'Young' women lost five years. Table 5 presents summary statistics for the 5,563 BHPS members retained in the sample for 1998. The first six columns report variable means or per centages positive for each of the six age-sex cells containing people born after 1931. The seventh column reports means and per centages positive for the entire sample.

The first row of Table 5 reports cell sizes. There are 1,204 'Young' women who lost five years of pension through the 1993 reform, and 894 'Old' women, who lost none. Thus despite deletions, the BHPS allows reasonable numbers of people in the relevant groups to be followed through all its eight waves. The second row gives average ages in 1998 in each cell. As row three shows, the mean number of children per household was low, at less than 0.6 for the entire sample. Row four reports high rates of marriage or cohabitation. This is due in 
Table 5 Summary statistics for individuals in British Household Panel Survey in 1998, only those who gave full answers in all waves from 1991 to 1998

\begin{tabular}{|c|c|c|c|c|c|c|c|}
\hline & Young & $\begin{array}{l}\text { Women } \\
\text { Middle-aged }\end{array}$ & Old & Young & $\begin{array}{c}\text { Men } \\
\text { Middle-aged }\end{array}$ & Old & All \\
\hline $\begin{array}{l}\text { Number in cell } \\
\text { Variable means }\end{array}$ & 1,204 & 349 & 894 & 963 & 293 & 727 & 5,563 \\
\hline Age & 33.4 & 45.4 & 55.9 & 33.1 & 45.2 & 56.1 & 49.9 \\
\hline $\begin{array}{l}\text { Number of own } \\
\text { children in } \\
\text { household } \\
\text { Percentages }\end{array}$ & 1.3 & 0.7 & 0.07 & 1 & 0.9 & 0.2 & 0.57 \\
\hline $\begin{array}{l}\text { Married or } \\
\text { cohabiting }\end{array}$ & 76.2 & 77.9 & 78.2 & 71.2 & 80.2 & 86.5 & 72 \\
\hline Employed & 76.7 & 78.8 & 54.5 & 92.7 & 87.7 & 67.3 & 60.8 \\
\hline Save & 44.4 & 47 & 45 & 50.5 & 46.8 & 46.9 & 44 \\
\hline $\begin{array}{l}\text { Contributes to } \\
\text { personal pension }\end{array}$ & 15.2 & 19.2 & 11.5 & 26.7 & 35.2 & 23.8 & 15.9 \\
\hline $\begin{array}{l}\text { Has divident or } \\
\text { interest income }\end{array}$ & 50.9 & 56.7 & 64.4 & 58.8 & 65.9 & 68.1 & 61.4 \\
\hline
\end{tabular}

Note: 'Young' implies born in or after 1956. 'Middle-aged' implies born from 1950 to 1955. 'Old' implies born from 1932 t0 1949. 1,133 people born prior to 1932 are included only in the 'All' column. Children are defined to be persons aged less than 16 .

*The full question was 'Do you save any amount of your income for example by putting something away now and then in a bank, building society or Post Office account other than to meet regular bills? Please include share purchase schemes and Personal Equity Plan Schemes.

part to the deletion of all observations for people who died between waves, who would disproportionately have been single. Under half of respondents reported that they saved, and only 16 per cent contributed to personal pensions. Over half reported having dividend or interest income, though most respondents were probably reporting bank or postal account interest.

\section{Regressions using the British Household Panel Survey}

Two types of regression are run to identify time-trends in saving behaviour using the BHPS. The first type produce year effects, to show the evolution of behaviour over time in as much detail as possible. Dependent variables associated with saving are regressed on year dummies and family status variables separately for each of the six age-sex cells defined above. The first year dummy is excluded, so the coefficients on the others show the changes in saving behaviour for the members of each cell relative to this first year. The dependent variables are all binary, so this study estimates probit models, such as

$$
S A V E_{i, t}=\Phi\left[\begin{array}{l}
b_{1} D\left(1991_{t}\right)+b_{2} D\left(1992_{t}\right)+\ldots \\
+b_{8} D\left(1998_{t}\right)+b_{9} M \text { MRRIED }_{i, t} \\
+b_{10} C_{i L D R E N}
\end{array}\right]
$$

using maximum likelihood. Here $\Phi$ is the cumulative normal density function, $S A V E$, the year terms and MARRIED are dummy variables, and CHILDREN is discrete. Many uses of panel data include person dummies to remove the influence of fixed individual characteristics. Our coefficients of interest, however, are on time dummies, which are by definition uncorrelated with any fixed personal characteristics. Therefore no bias in the time coefficients is created by my omission of person dummies. The likelihood of the data is a function of the 
Table 6 Probit regressions of 'Do you save each month?', panel from BHPS, leavers and joiners excluded. Coefficients are changes in probabilities, multiplied by 100

\begin{tabular}{|c|c|c|c|c|c|c|}
\hline \multirow[b]{2}{*}{ Pension lost } & \multicolumn{3}{|c|}{ Women by year of birth } & \multicolumn{3}{|c|}{ Men by year of birth } \\
\hline & $\begin{array}{l}1956-76 \\
5 \text { years }\end{array}$ & $\begin{array}{l}1950-55 \\
0-5 \\
\text { years }\end{array}$ & $\begin{array}{l}\text { 1932-49 } \\
\text { None }\end{array}$ & $\begin{array}{l}\text { 1956-76 } \\
\text { None }\end{array}$ & $\begin{array}{l}\text { 1950-55 } \\
\text { None }\end{array}$ & $\begin{array}{l}\text { 1932-49 } \\
\text { None }\end{array}$ \\
\hline \multicolumn{7}{|l|}{$\triangle$ Pr. relative to 1991} \\
\hline 1992 & $\begin{array}{l}-4.3 \\
(2)\end{array}$ & $\begin{array}{c}1.3 \\
(3.8)\end{array}$ & $\begin{array}{c}-0.52 \\
(2.3)\end{array}$ & $\begin{array}{r}-3.8 \\
(2.3)\end{array}$ & $\begin{array}{r}-3.5 \\
(4.1)\end{array}$ & $\begin{array}{l}-4 \\
(2.6)\end{array}$ \\
\hline 1993 & $\begin{array}{l}1.1 \\
(2.1)\end{array}$ & $\begin{array}{c}3.6 \\
(3.8)\end{array}$ & $\begin{array}{c}-1.3 \\
(2.3)\end{array}$ & $\begin{array}{l}2.4 \\
(2.3)\end{array}$ & $\begin{array}{l}-5 \\
(4.1)\end{array}$ & $\begin{array}{r}-3.7 \\
(2.6)\end{array}$ \\
\hline 1994 & $\begin{array}{c}-0.5 \\
(2.1)\end{array}$ & $\begin{array}{c}-0.2 \\
(3.8)\end{array}$ & $\begin{array}{c}-5.3 \\
(2.3)\end{array}$ & $\begin{array}{c}-0.7 \\
(2.3)\end{array}$ & $\begin{array}{c}-4.5 \\
(4.1)\end{array}$ & $\begin{array}{r}-2.8 \\
(2.6)\end{array}$ \\
\hline 1995 & $\begin{array}{c}0.5 \\
(2.1)\end{array}$ & $\begin{array}{c}0.6 \\
(3.8)\end{array}$ & $\begin{array}{c}-3.5 \\
(2.4)\end{array}$ & $\begin{array}{l}1.3 \\
(2.3)\end{array}$ & $\begin{array}{c}-5.4 \\
(4.1)\end{array}$ & $\begin{array}{l}-6 \\
(2.6)\end{array}$ \\
\hline 1996 & $\begin{array}{c}0.3 \\
(2.1)\end{array}$ & $\begin{array}{c}0.3 \\
(3.8)\end{array}$ & $\begin{array}{c}-1.4 \\
(2.4)\end{array}$ & $\begin{array}{l}2.5 \\
(2.3)\end{array}$ & $\begin{array}{r}-6.4 \\
(4.1)\end{array}$ & $\begin{array}{r}-5.5 \\
(2.6)\end{array}$ \\
\hline 1997 & $\begin{array}{l}0.3 \\
(2.1)\end{array}$ & $\begin{array}{c}0.5 \\
(3.8)\end{array}$ & $\begin{array}{r}-1.2 \\
(2.4)\end{array}$ & $\begin{array}{l}3.6 \\
(2.3)\end{array}$ & $\begin{array}{c}-6.2 \\
(4.1)\end{array}$ & $\begin{array}{c}-4.2 \\
(2.6)\end{array}$ \\
\hline 1998 & $\begin{array}{l}1 \\
(2.1)\end{array}$ & $\begin{array}{c}2.2 \\
(3.9)\end{array}$ & $\begin{array}{c}-0.58 \\
(2.4)\end{array}$ & $\begin{array}{l}3.9 \\
(2.3)\end{array}$ & $\begin{array}{r}-5.5 \\
(4.1)\end{array}$ & $\begin{array}{r}-3.4 \\
(2.6)\end{array}$ \\
\hline $\begin{array}{l}\text { Controls } \\
\text { Married }\end{array}$ & $\begin{array}{r}9.9 \\
(1.2)\end{array}$ & $\begin{array}{l}13.5 \\
(2.3)\end{array}$ & $\begin{array}{c}10.4 \\
(1.4)\end{array}$ & $\begin{array}{c}2.3 \\
(1.4)\end{array}$ & $\begin{array}{c}6.4 \\
(2.9)\end{array}$ & $\begin{array}{r}6.9 \\
(1.9)\end{array}$ \\
\hline No. of children & $\begin{array}{r}-11.6 \\
(0.5)\end{array}$ & $\begin{array}{c}-6.8 \\
(1)\end{array}$ & $\begin{array}{r}-1.9 \\
(1.2)\end{array}$ & $\begin{array}{c}-6.2 \\
(0.6)\end{array}$ & $\begin{array}{c}-3.2 \\
(1)\end{array}$ & $\begin{array}{l}-5.4 \\
(1)\end{array}$ \\
\hline Log likelihood & $-6,320$ & $-1,877$ & $-4,860$ & $-5,274$ & $-1,613$ & $-3,991$ \\
\hline $\mathrm{N}$ & 1,204 & 349 & 894 & 963 & 293 & 727 \\
\hline NT & 9,632 & 2,792 & 7,152 & 7,704 & 2,344 & 5,816 \\
\hline
\end{tabular}

Note: Standard errors, also multiplied by 100 , are in parentheses. There are no person dummies.

coefficients $b$; computer packages maximise the log of this likelihood over $b$ using iterative algorithms.

Table 6 reports regressions of answers to 'Do you save, other than to meet regular bills? ${ }^{27}$ The year coefficients are the per centage-point change of positive answers relative to 1991 . The horizontal line after 1993 shows the rough date of the reform announcement. ${ }^{28}$ The first column gives results for 'Young' women, who lost five years of pension. There was a dip in answers of 'yes' in 1992, but no upward spike in saving after 1993. Significantly more married than unmarried women saved, while the presence of children in the household depressed saving. Both results extend to men and women of all ages. The second column reports coefficients for women who lost up to five years' pension. None of the year coefficients here are significant. The third column analyses
'Old' women, who lost nothing. They became significantly less likely to report saving in 1994, consistent with the hypothesis of a positive 'wealth surprise' for them in the 1993 announcement. The proportion of older women saving had recovered by 1998, however, so this 'positive surprise' case is not entirely convincing.

Young men are examined in column four of Table 6 . They were significantly more likely to save from 1997 on. The most plausible explanation is that young men are more likely to save as their earnings increase with age. Middle-aged men, in column five, show no significant year coefficients. 'Old' men were significantly less likely to save after 1995 , which might reflect a positive wealth surprise of the pension announcement, or instead workers' starting to consume their assets upon retirement. Overall in Table 6 it can be seen that reported 
Table 7 Probit regressions of 'Did you contribute to a personal pension last year?', panel from BHPS, leavers and joiners excluded. Coefficients are changes in probabilities, multiplied by 100

\begin{tabular}{|c|c|c|c|c|c|c|}
\hline \multirow[b]{2}{*}{ Pension lost } & \multicolumn{3}{|c|}{ Women by year of birth } & \multicolumn{3}{|c|}{ Men by year of birth } \\
\hline & $\begin{array}{l}1956-76 \\
5 \text { years }\end{array}$ & $\begin{array}{l}1950-55 \\
0-5 \\
\text { years }\end{array}$ & $\begin{array}{l}\text { 1932-49 } \\
\text { None }\end{array}$ & $\begin{array}{l}\text { 1956-76 } \\
\text { None }\end{array}$ & $\begin{array}{l}\text { 1950-55 } \\
\text { None }\end{array}$ & $\begin{array}{l}\text { 1932-49 } \\
\text { None }\end{array}$ \\
\hline \multicolumn{7}{|l|}{$\triangle$ Pr. relative to 1992} \\
\hline 1993 & $\begin{array}{l}2.2 \\
(1.5)\end{array}$ & $\begin{array}{l}0.1 \\
(3)\end{array}$ & $\begin{array}{c}2.4 \\
(1.7)\end{array}$ & $\begin{array}{l}-0.3 \\
(2)\end{array}$ & $\begin{array}{r}-1.1 \\
(3.9)\end{array}$ & $\begin{array}{l}2.1 \\
(2.3)\end{array}$ \\
\hline 1994 & $\begin{array}{l}2.1 \\
(1.5)\end{array}$ & $\begin{array}{c}-2.6 \\
(2.8)\end{array}$ & $\begin{array}{c}0.7 \\
(1.6)\end{array}$ & $\begin{array}{c}0.2 \\
(2)\end{array}$ & $\begin{array}{l}0.5 \\
(3.9)\end{array}$ & $\begin{array}{l}0.2 \\
(2.3)\end{array}$ \\
\hline 1995 & $\begin{array}{c}1.4 \\
(1.5)\end{array}$ & $\begin{array}{l}0.1 \\
(3)\end{array}$ & $\begin{array}{r}0.5 \\
(1.6)\end{array}$ & $\begin{array}{l}-1.7 \\
(2)\end{array}$ & $\begin{array}{c}2 \\
(4)\end{array}$ & $\begin{array}{c}-3.1 \\
(2.2)\end{array}$ \\
\hline 1996 & $\begin{array}{c}0.9 \\
(1.5)\end{array}$ & $\begin{array}{l}-0.7 \\
(3)\end{array}$ & $\begin{array}{r}-1.9 \\
(1.5)\end{array}$ & $\begin{array}{l}-2.5 \\
(2)\end{array}$ & $\begin{array}{r}-0.6 \\
(3.9)\end{array}$ & $\begin{array}{c}-2.9 \\
(2.2)\end{array}$ \\
\hline 1997 & $\begin{array}{r}1.9 \\
(1.5)\end{array}$ & $\begin{array}{r}-2.6 \\
(2.8)\end{array}$ & $\begin{array}{r}-1.1 \\
(1.5)\end{array}$ & $\begin{array}{l}-2.1 \\
(2)\end{array}$ & $\begin{array}{c}-2.1 \\
(3.9)\end{array}$ & $\begin{array}{c}-3.7 \\
(2.2)\end{array}$ \\
\hline 1998 & $\begin{array}{r}1.9 \\
(1.5)\end{array}$ & $\begin{array}{r}-2.8 \\
(2.8)\end{array}$ & $\begin{array}{r}-1.4 \\
(1.5)\end{array}$ & $\begin{array}{l}-2.6 \\
(2)\end{array}$ & $\begin{array}{l}1.1 \\
(4)\end{array}$ & $\begin{array}{c}-4.5 \\
(2.2)\end{array}$ \\
\hline Controls & 5.1 & -0.03 & 1.4 & 13.2 & 4.2 & 9.7 \\
\hline Married & $(0.8)$ & $(2)$ & $(1)$ & (1.3) & (2.9) & (1.7) \\
\hline No. of children & $\begin{array}{r}-4.6 \\
(0.4)\end{array}$ & $\begin{array}{c}-4.7 \\
(0.9)\end{array}$ & $\begin{array}{r}-1.3 \\
(0.9)\end{array}$ & $\begin{array}{c}-2.2 \\
(0.6)\end{array}$ & $\begin{array}{l}-2.2 \\
(1)\end{array}$ & $\begin{array}{r}0.35 \\
(0.98)\end{array}$ \\
\hline $\begin{array}{l}\text { Log likelihood } \\
\mathrm{N}\end{array}$ & $\begin{array}{r}-3,490 \\
1.204\end{array}$ & $\begin{array}{r}-1,180 \\
349\end{array}$ & $\begin{array}{c}-2,372.1 \\
894\end{array}$ & $\begin{array}{r}-1,304 \\
293\end{array}$ & $\begin{array}{r}-1,304 \\
293\end{array}$ & $\begin{array}{c}-2,930.8 \\
727\end{array}$ \\
\hline NT & 8,428 & 2,443 & 6,258 & 2,051 & 2,051 & 5,089 \\
\hline
\end{tabular}

Note: Standard errors, also multiplied by 100 , are in parentheses. There are no person dummies.

saving by women was very stable over time. The only evidence for the life-cycle hypothesis is that consistent with a positive 'wealth surprise' for older men and women.

Table 7 reports similar regressions for the question 'Did you contribute to a Personal Pension in the last year?', which translates to 'since last August', as almost all interviews occurred in that month. This question was not asked in 1991, so the dummy for 1992 is excluded and the coefficients are per centage-point changes in the proportion answering 'yes' relative to that year. In the first column, it can be seen that contribution by young women was very stable. None of the year coefficients is significant and there is no spike in contribution after 1993. There are few significant coefficients in the other columns either, so personal pension membership was approximately static in all sex and cohort categories. 'Old' men became significantly less likely to contribute in 1998 , perhaps again due to retirement on their part. The results in Table 7 give no support to the life-cycle theory.

Table 8 gives results for the question 'Did you have dividend or interest income last year?' The first column shows young women became substantially more likely to have such income in 1993, and again from 1995 on. There is no upward spike in asset income in 1994 but instead a slight fall. Among the older cohorts of women, none of the year coefficients are significant. In columns four to six it can be seen that significantly more young men had dividend or interest income from 1995 on, whereas no significant changes are visible among older men. The most plausible explanation for the growth in the proportion of the young with asset income is again a gradual build-up of financial assets as young people become wealthier with age. 
Table 8 Probit regressions of 'Did you have dividend or interest income last year?', panel from BHPS, leavers and joiners excluded. Coefficients are changes in probabilities, multiplied by 100

\begin{tabular}{|c|c|c|c|c|c|c|}
\hline \multirow[b]{2}{*}{ Pension lost } & \multicolumn{3}{|c|}{ Women by year of birth } & \multicolumn{3}{|c|}{ Men by year of birth } \\
\hline & $\begin{array}{l}1956-76 \\
5 \text { years }\end{array}$ & $\begin{array}{l}1950-55 \\
0-5 \\
\text { years }\end{array}$ & $\begin{array}{l}\text { 1932-49 } \\
\text { None }\end{array}$ & $\begin{array}{l}\text { 1956-76 } \\
\text { None }\end{array}$ & $\begin{array}{l}\text { 1950-55 } \\
\text { None }\end{array}$ & $\begin{array}{l}\text { 1932-49 } \\
\text { None }\end{array}$ \\
\hline \multicolumn{7}{|l|}{$\triangle$ Pr. relative to 1991} \\
\hline 1992 & $\begin{array}{c}0.2 \\
(2.1)\end{array}$ & $\begin{array}{c}-4.2 \\
(3.8)\end{array}$ & $\begin{array}{c}1.4 \\
(2.3)\end{array}$ & $\begin{array}{c}-0.4 \\
(2.3)\end{array}$ & $\begin{array}{l}0.3 \\
(4)\end{array}$ & $\begin{array}{r}-0.1 \\
(2.5)\end{array}$ \\
\hline 1993 & $\begin{array}{l}4.6 \\
(2.1)\end{array}$ & $\begin{array}{c}-0.2 \\
(3.8)\end{array}$ & $\begin{array}{c}0.6 \\
(2.3)\end{array}$ & $\begin{array}{l}2.4 \\
(2.2)\end{array}$ & $\begin{array}{c}-3.2 \\
(4.1)\end{array}$ & $\begin{array}{r}-0.2 \\
(2.5)\end{array}$ \\
\hline 1994 & $\begin{array}{l}2 \\
(2.1)\end{array}$ & $\begin{array}{c}-1.5 \\
(3.8)\end{array}$ & $\begin{array}{c}0.5 \\
(2.3)\end{array}$ & $\begin{array}{l}1.7 \\
(2.3)\end{array}$ & $\begin{array}{c}-3.9 \\
(4.1)\end{array}$ & $\begin{array}{r}-1.3 \\
(2.5)\end{array}$ \\
\hline 1995 & $\begin{array}{l}6.2 \\
(2.1)\end{array}$ & $\begin{array}{c}-0.3 \\
(3.8)\end{array}$ & $\begin{array}{l}2.7 \\
(2.3)\end{array}$ & $\begin{array}{c}4.4 \\
(2.2)\end{array}$ & $\begin{array}{c}-3.4 \\
(4.1)\end{array}$ & $\begin{array}{r}-1.3 \\
(2.5)\end{array}$ \\
\hline 1996 & $\begin{array}{l}5.4 \\
(2.1)\end{array}$ & $\begin{array}{c}-0.5 \\
(3.8)\end{array}$ & $\begin{array}{c}0.4 \\
(2.3)\end{array}$ & $\begin{array}{l}3.3 \\
(2.2)\end{array}$ & $\begin{array}{c}-6.3 \\
(4.1)\end{array}$ & $\begin{array}{r}-0.9 \\
(2.5)\end{array}$ \\
\hline 1997 & $\begin{array}{l}4.7 \\
(2.1)\end{array}$ & $\begin{array}{c}-0.3 \\
(3.8)\end{array}$ & $\begin{array}{c}0.6 \\
(2.3)\end{array}$ & $\begin{array}{c}4.3 \\
(2.2)\end{array}$ & $\begin{array}{c}-2.4 \\
(4.1)\end{array}$ & $\begin{array}{r}-1.6 \\
(2.5)\end{array}$ \\
\hline 1998 & $\begin{array}{l}4.1 \\
(2.1)\end{array}$ & $\begin{array}{c}-0.9 \\
(3.8)\end{array}$ & $\begin{array}{l}2.3 \\
(2.3)\end{array}$ & $\begin{array}{l}5.4 \\
(2.6)\end{array}$ & $\begin{array}{l}-3 \\
(4.1)\end{array}$ & $\begin{array}{r}0.4 \\
(2.5)\end{array}$ \\
\hline $\begin{array}{l}\text { Controls } \\
\text { Married }\end{array}$ & $\begin{array}{l}18.7 \\
(1.2)\end{array}$ & $\begin{array}{l}14.7 \\
(2.4)\end{array}$ & $\begin{array}{l}13.9 \\
(1.46)\end{array}$ & $\begin{array}{l}9.9 \\
(1.4)\end{array}$ & $\begin{array}{l}9.9 \\
(3)\end{array}$ & $\begin{array}{c}9.7 \\
(1.9)\end{array}$ \\
\hline No. of children & $\begin{array}{r}-12.9 \\
(0.5)\end{array}$ & $\begin{array}{l}-1.2 \\
(1)\end{array}$ & $\begin{array}{r}-3.8 \\
(1.1)\end{array}$ & $\begin{array}{r}-6.6 \\
(0.6)\end{array}$ & $\begin{array}{l}-5.5 \\
(1)\end{array}$ & $\begin{array}{r}-3.8 \\
(0.9)\end{array}$ \\
\hline $\begin{array}{l}\text { Log likelihood } \\
\mathrm{N}\end{array}$ & $\begin{array}{c}-6,295 \\
1,204\end{array}$ & $\begin{array}{r}-1,892 \\
349\end{array}$ & $\begin{array}{c}-4,664 \\
894\end{array}$ & $\begin{array}{c}-5,220 \\
963\end{array}$ & $\begin{array}{r}-1,504 \\
293\end{array}$ & $\begin{array}{c}-3,679 \\
727\end{array}$ \\
\hline NT & 9,632 & 2,792 & 7,152 & 7,604 & 2,344 & 5,816 \\
\hline
\end{tabular}

Note: Standard errors, also multiplied by 100 , are in parentheses. There are no person dummies.

The second set of regressions with the BHPS summarises the evidence of the first set and construct formal differences in differences and triple differences. The entire 5,563-person panel is used, with the specification (see bottom of page).

Here YOUNG and OLD are defined by birth cohort as above, BEFORE is a dummy equal to one if the observation comes from 1991 to 3 and AFTER a dummy equal to one if the observation dates from 1994 or after. The coefficients of interest are $b_{8}$ through $b_{11}$ on the interactions between age, sex and
AFTER, as the coefficients on these interactions reflect changes relative to behaviour before the announcement. The difference

$$
\left(b_{8}-b_{9}\right)
$$

is the difference-in-differences in behaviour between 'pension-losing' and 'pension-retaining' women across the 1993 reform. Under the life-cycle hypothesis, it will be positive. This could either be because a negative 'wealth surprise' for young women led more of them to save, so $b_{8}$ is positive, or because

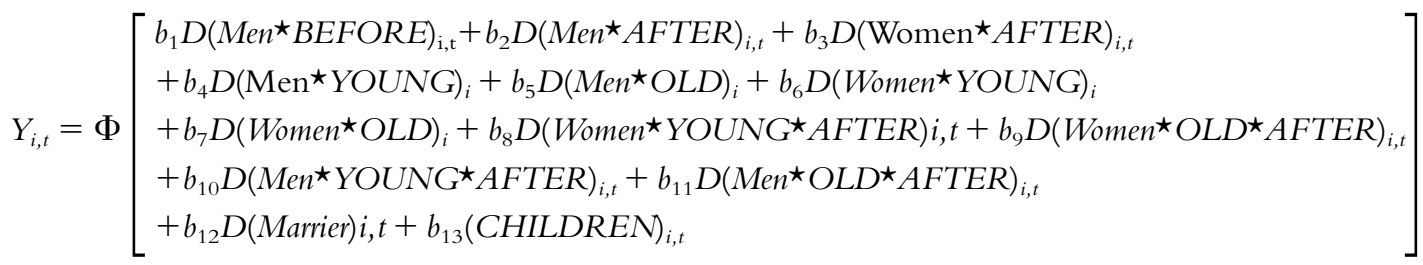


Table 9 Probit regressions showing differences in differences, pooled BHPS sample. Coefficients are changes in probabilities multiplied by 100

\begin{tabular}{|c|c|c|c|}
\hline & Save & Private pension & $\begin{array}{l}\text { Dividend/interest } \\
\text { income }\end{array}$ \\
\hline \multicolumn{4}{|l|}{$\triangle P r$ relative to women before reform } \\
\hline Men ${ }^{*}$ Before reform & $\begin{array}{l}5.3 \\
(1.4)\end{array}$ & $\begin{array}{c}10.8 \\
(1.8)\end{array}$ & $\begin{array}{c}7.3 \\
(1.3)\end{array}$ \\
\hline MenAfter reform & $\begin{array}{l}2.3 \\
(1.2)\end{array}$ & $\begin{array}{l}8.9 \\
(1.3)\end{array}$ & $\begin{array}{l}3.7 \\
(1.2)\end{array}$ \\
\hline Women*After reform & $\begin{array}{l}3.8 \\
(1.5)\end{array}$ & $\begin{array}{c}-0.1 \\
(1.2)\end{array}$ & $\begin{array}{l}-2 \\
(1.1)\end{array}$ \\
\hline Young*Men & $\begin{array}{l}8.8 \\
(1.4)\end{array}$ & $\begin{array}{c}14.1 \\
(1.6)\end{array}$ & $\begin{array}{r}-17.6 \\
(1.5)\end{array}$ \\
\hline OldMen & $\begin{array}{l}3.8 \\
(1.5)\end{array}$ & $\begin{array}{c}13.6 \\
(1.7)\end{array}$ & $\begin{array}{r}-10.7 \\
(1.6)\end{array}$ \\
\hline Young ${ }^{*}$ Women & $\begin{array}{c}12.4 \\
(1.3)\end{array}$ & $\begin{array}{l}11.6 \\
(1.6)\end{array}$ & $\begin{array}{r}-12.4 \\
(1.3)\end{array}$ \\
\hline Old*Women & $\begin{array}{l}6.6 \\
(4.9)\end{array}$ & $\begin{array}{l}9.3 \\
(1.7)\end{array}$ & $\begin{array}{r}-7.9 \\
(1.4)\end{array}$ \\
\hline Young ${ }^{\star}$ Women ${ }^{\star}$ After & $\begin{array}{l}0.1 \\
(1.6)\end{array}$ & $\begin{array}{r}-0.3 \\
(1.5)\end{array}$ & $\begin{array}{c}4.3 \\
(1.5)\end{array}$ \\
\hline OldWomen*After & $\begin{array}{l}-2.5 \\
(1.7)\end{array}$ & $\begin{array}{r}-1.6 \\
(1.5)\end{array}$ & $\begin{array}{l}1.7 \\
(1.6)\end{array}$ \\
\hline Diff-in-diffs significant? (women) & No & No & No \\
\hline Young*MenAfter & $\begin{array}{l}6 \\
(1.8)\end{array}$ & $\begin{array}{l}-0.1 \\
(1.4)\end{array}$ & $\begin{array}{l}7 \\
(1.7)\end{array}$ \\
\hline Old*Men*After & $\begin{array}{l}1.1 \\
(1.9)\end{array}$ & $\begin{array}{r}-1.8 \\
(1.4)\end{array}$ & $\begin{array}{l}2.2 \\
(1.9)\end{array}$ \\
\hline Triple-diff significant? & No & No & \\
\hline $\begin{array}{l}\text { Log likelihood } \\
\text { NT }\end{array}$ & $\begin{array}{r}-30,002 \\
44,504\end{array}$ & $\begin{array}{r}-16,684 \\
38,941\end{array}$ & $\begin{array}{l}\text { No } \\
-28,645 \\
44,504\end{array}$ \\
\hline
\end{tabular}

Note: The number of children and a 'part of couple' dummy were included in all regressions. Standard errors, also multiplied by 100 are in parentheses. The diffs-in-diffs are tested at the t per cent significance level using two-tailed tests.

old women had a positive surprise, so b9 is negative, or a mixture of the two.

This difference-in-differences thus tests the life-cycle hypothesis under a range of expectational hypotheses. The difference-in-differences between young and old men is $\left(b_{10}-b_{11}\right)$, so the triple difference is

$$
\left(b_{8}-b_{9}\right)-\left(b_{10}-b_{11}\right)
$$

Table 9 reports difference regressions such as (4) for each binary dependent variable. The coefficients are again per centage changes in the probability of an affirmative answer. The last four coefficients, $b_{8}$ through $b_{11}$, are those of particular interest. The first column examines answers to the question 'Do you save?' Row eight shows that 0.1 per cent more young women saved after 1993. Row nine shows that 2.5 per cent fewer 'Old' women saved after the announcement. The probit equivalent of a two-tailed $t$ test can be applied to the difference between these coefficients, and row ten reports that no difference was found at the 5 per cent significance level. Row eleven reports a 6 per cent increase in the number of 'Young' men saving after 1993, while in row twelve 1.1 per cent more 'Old' men saved after the announcement. The large increase in saving by young men means the triple difference (6) in the proportions saving has the opposite sign to that implied by the life-cycle theory, but, as row thirteen reports, this was not significant either. Thus answers to 'Do you save?' 
do not support the life-cycle

hypothesis.

Column two of Table 9 gives results for answers to 'Did you contribute to a Personal Pension in the last year?' The last four coefficients show that slightly fewer men and women in each age group did so. The coefficients are all small in relation to their standard errors, so again neither the difference-in-differences among women nor the triple difference in saving is significant. There is thus no support for the life-cycle hypothesis in personal pension contribution rates in the BHPS. Column three examines the proportion of people declaring dividend or interest income. Row eight shows that 4.3 per cent more 'Young' women had such income after 1993. This is insignificantly greater than the 1.7 per cent increase among 'Old' women, as row ten states. Rows eleven and twelve show a similar pattern among men, so the triple difference in declarations of dividend and interest income is not significant. Thus Table 9 repeats the evidence of Tables 6 through 8 in a more formal manner. Neither the difference-indifference nor the triple-difference tests evince a life-cycle saving response to the 1993 announcement. In Table 6, the fall in the number of 'Old' women who saved in 1994 suggested a positive 'wealth surprise' on their part.

However, because saving by 'Old' women then recovered after 1994, the post-1993 differences are too small to be significant.

\section{Regressions using the FES}

Similar regressions to those above were run on data from the FES. They are not reported in full here, since they also found no response to the 1993 reform. ${ }^{29}$ Although the FES does not follow households over time, 'pension-losing' and 'pension-retaining' households containing married couples can be defined in each survey according to the wife's age. Variables recording ownership of Tax-Exempt Special Savings Accounts $\left(\right.$ TESSAs) ${ }^{30}$ and households' income from equity or bonds show no evidence of responses to the 1993 pension reform announcement either by 'pension-losers' or 'pension-retainers'. Among households containing 28 to 37 -year-old wives, there is a minimal increase in the proportion declaring income from equity or bonds over time, from 30 per cent in 1992 to 33 per cent in 1998-9. This stability in dividend and interest income once age is held constant reinforces the conclusion that the increases in declarations of asset income by young people in the BHPS reflect ageing rather than a behavioural change.

\section{Conclusions}

This paper finds very little evidence of a saving response to the announcement in 1993 that British women's state pension age would rise from 60 to 65 between 2010 and 2020. Of many coefficients tested, only one, showing a dip in older women's saving in 1994, was significant in the predicted direction, so the null of no response cannot be rejected. No upward step in saving by young women after 1993 is evident. The strongest patterns in the data are large rises and falls in membership rates of personal and occupational pensions, which appear attributable to the personal pension 'mis-selling scandal' of 1993 onward. Optimal responses of life-cycle savers to the 1993 announcement, equivalent to a loss of at least $£ 3,400$ for women born in 1955, would have been fairly small. Thus this paper constructs a rather weak test of the life-cycle consumption hypothesis. 
The finding of no response is consistent with the life-cycle hypothesis if women anticipated both the higher pension age and the manner of phasing it in before 1993. Such accurate expectations are implausible, however. The absence of a saving response to lowered pension wealth is consistent with the 'dynastic' theory of consumption. This states that younger women only reduced their planned bequests to their children when learning of the 1993 reform. This implication of great sophistication in workers' calculations may again be implausible. The simplest conclusion to the evidence of this paper is that young women were simply 'myopic', not responding to the announcement because their retirements were so far in the future that they omitted to plan for them.

Myopic saving behaviour implies private saving is insensitive to state pensions' existence, and therefore that state pension systems do not in fact reduce national saving. It also implies a problem of supporting old people who never saved. Policy initiatives based on voluntary, tax-preferred instruments such as the UK's 'Stakeholder Pensions' may fail in the face of consumer myopia. There are now also disincentives for voluntary saving because of means and asset tests in the Minimum Income Guarantee, a benefit for poor pensioners introduced in 1999, and other asset tests in the social insurance system. Thus state compulsion to save may be desirable, and the UK has some coercion to save, since workers can only leave SERPS by joining an approved private pension. Perhaps public education is the best response to myopia: campaigns in the West to encourage 'responsible sexual behaviour' were successful in containing AIDS; perhaps ageing societies need campaigns for 'responsible saving behaviour'.

\section{Appendix A: The budget speech given by Chancellor of the Exchequer Kenneth Clarke in the UK House of Commons on November 30th 1993}

The part of the speech relevant to the state pension age for women was as follows:

'I can announce one further decision which will have little immediate effect, but will make a considerable difference to the affordability of the modern welfare state in the next century.

'After careful consideration, the government has decided that the state pension age should eventually be equalised at 65 . The change will be phased in over ten years, starting in the year 2010, so it will not affect anyone currently aged 44 or older. By the year 2020, the state pension age in Britain will be broadly in line with that of most of our industrial competitors, though we will still have more generous arrangements than in the United States, where the pension age is to be equalised at 67 .

'All developed countries are making similar changes for similar reasons. Women nowadays tend to spend more of their lives in paid employment. They also live longer than men. Pension schemes need to recognise this, and end the current discrimination between sexes.

'In the next century, the ratio of working people to retired people will fall sharply and the burdens on taxpayers will rise. The government's decisions will moderate those burdens, eventually by some $£, 5$ billion a year, and so help to ensure that they are sustainable. The basic pension is, and will remain, a cornerstone of the welfare state. The government is committed to it and to retaining its value.

'The proposals I have announced today will in themselves save some two and a half billion pounds a year by 1996-97. Nevertheless, even taking these savings into account, we will still be spending $\mathcal{E}^{5}$ billion more on social security in that year than we planned last year. The social security budget will continue to grow in real terms, but at a 
more affordable rate than we have seen in recent years. At the same, we have honoured our manifesto commitments; we have fully protected the real value of pensions and benefits; and have provided generous help with fuel bills.

'These are not short-term measures to deal with today's problems. This government has the courage to take a clear and far-sighted view of the modern social security system. We must make sure that it is a system that future generations will be able to afford. 'This government will never take part in any attempt to dismantle the welfare state. We want to see a better welfare state; well-run, well-judged and one that meets the priorities of modern society.'

\section{Appendix B: Manipulation of the BHPS data}

The results of all eight waves of the BHPS to date were also supplied by the Data Archive at the University of Essex. The following variables were extracted from each wave:

pid Person identification number age Age at date of interview doim Month of interview

doiy4 Year of interview

dobm Date of birth - month

doby Date of birth - year

saved Answers to 'Do you save?

pppen Did respondent, during the last year, contribute to a private personal pension or have such contributions paid on his or her behalf by the Department of Social Security? This question was not asked in 1991.

fiyrdi Income last year from dividends or interest.

jbhas Did respondent do paid work last week?

jboff Did respondent have job but do no paid work last week?

nchild Number of respondent's own children in the household. This includes natural children, adopted children, and step children.

mastat Marital status. 'Married', 'Living as Couple' and 'Separated' are different categories.

These data were then stacked together, producing up to eight records for each respondent.

\section{Re-coding of interview dates}

96.2 per cent of BHPS interviews take place from August to the end of November of the given year.

Difficulties in contacting some people mean that 1.6 per cent of interviews take place from January to May of the following year. Therefore some people were interviewed no times in one calendar year but twice in the next, a problem in the present context because a year effect could be particularly influenced by those people interviewed twice that year. Therefore the author re-coded all interviews conducted from January to the end of July as having occurred in the previous year. This ensures that each person is interviewed once per re-coded year. Some precision is lost in the interpretation of the year effects, as now these are more properly 'wave effects'. Since this re-coding only affects 1.6 per cent of interviews, it probably makes little difference to the overall results.

\section{Deletion of observations with missing data}

Any observations where the answers to 'Did you save?' or 'What is your marital status?' were 'Don't Know' or 'Refused' were dropped. Any observations from after 1991 where answers to the Personal Pension question were 'Don't Know' or 'Refused' were also dropped. 


\section{Deletion of leavers, joiners, and people with missing data}

The following algorithm ${ }^{31}$ is used for deleting survey leavers, joiners, and people who did not answer all the relevant questions in all waves:

1 Generate the variable 'score' by person identification number, equal to the sum of the values of doiy 4 for that person, where doiy 4 as re-coded equalled the year from which the interview 'should' have come.

2 Drop all observations for which the variable 'score' does not equal 15956.

This algorithm drops from the data set people who failed to answer the questions 'Did you save?' or 'Did you contribute to a Personal Pension?' in any year, ensuring that all the measured changes in saving result from changes in behaviour, rather than changes in data quality.

\section{Correction of birth dates}

Quite a number of people in the reduced sample declared different years of birth in different waves of the BHPS, in one case making an error of ten years. ${ }^{32} \mathrm{~A}$ variable recording the mean birth year reported by each sample member was thus created. Reporting errors may be identified whenever this variable has a non-integer value.

\section{Generation of dummy variables}

The remaining data for pppen and saved were coded yes $=1$ or no $=2$, so these had to be re-coded to produced dummy variables. The other dummy variables generated were:

Variable Equal to Unity If and Only If divint Dividend and interest income flyrdi $>0$ married Marital status mastat either 'married' or 'living as couple'

employed Either jbhas $=$ yes or jboff $=$ yes

before Interview came from waves $1-3$

after Interview came from waves 4-8

oldmen $\quad$ Sex $=$ male and doby from 1932 to 1949

Other sex-birth year cohort dummies were defined analogously to 'oldmen'. The coding of the 'before' and 'after' variables does not exactly divide the interviews into those occurring before and after the 1993 announcement, since interviews from December 1993 to March 1994 are erroneously coded as occurring 'before' it. This does ensure exactly the same people are treated as having been interviewed before and after the reform, however. Again, 96.16 per cent of all interviews were conducted between August and the end of November each year, so very few interviews can be incorrectly assigned to 'before' the announcement of November 30th 1993.

Interaction terms used in the difference-in-difference regressions were constructed using these 'before', 'after' and cohort dummies.

\section{Acknowledgment}

The British Household Panel Survey and Family Expenditure Survey were supplied by the Data Archive at the University of Essex, England, which is supported by the Economic and Social Research Council. I am grateful to Robin Ellison of the Eversheds Law Firm, Louise Pigott of CGU Life, Emma Boyd of Equitable Life, and the staffs of the UK Office for National Statistics and Department of Social Security for their responses to my queries. I am also grateful to David Cutler, Larry Katz and Martin Feldstein for their advice and comments.

\section{References}

1 State pensions are, however, taxable, so they could push a few recipients into a higher income tax bracket and thereby change their after-tax wages. 
2 National Insurance Contributions, the British name for payroll taxes, would eventually be lower as a result of this reform. The author ignores any effect of these lower payroll taxes on women's projected labour supply.

3 Barro, R. (1974) 'Are Government Bonds Net Wealth?', Journal of Political Economy.

4 Feldstein, M. (1974) 'Social Security, Induced Retirement and Aggregate Capital Accumulation', Journal of Political Economy, September/October.

5 Feldstein, M. (1996) 'Social Security and Saving: New Time Series Evidence', National Tax Journal Vol. 49 No.2, June.

6 Leimer, D. and Lesnoy, S. (1082) 'Social Security and Savings: New Time Series Evidence', Journal of Political Economy, pp. 606-642.

7 Meguire, P. (1998) 'Comment: Social Security and Private Savings', National Tax Journal, Vol. 51, No. 2, June.

8 Feldstein, M. (1980) 'International Differences in Social Security and Saving', Journal of Public Economics Vol. 12.

9 Edwards, S. (1995) 'Why Are Saving Rates so Different Across Countries? An International Comparative Analysis', NBER Working Paper No. 5097, April.

10 Bernheim, B. Douglas and Levin, L. (1989) American Economic Review, Vol. 79, No. 2, May.

11 SERPS has since been renames the State Second Pension.

12 The National Association of Pension Funds' 1993 survey found that 84 per cent of schemes imposed no reduction in pensions in respect of service prior to 17th May, 1990. Much of the information in this paragraph is taken from Luckhaus and Moffat (1996).

13 Disney, R. and Whitehouse, E. (1992) 'The Personal Pensions Stampede', published by The Institute for Fiscal Studies.

14 The Minimum Income Guarantee is not relevant here as it was only introduced in 1999.

15 Income testing of the Basic Pension was ended in October 1989

16 Blake, D. (1995) 'Pension Schemes and Pension Funds in the United Kingdom', Clarendon Press.

17 Dilnot, A., Disney, R., Johnson, P. and Whitehouse, E. (1994) 'Pensions Policy in the UK', published by The Institute for Fiscal Studies.

18 The relevent part of the budget speech is reproduced in Appendix A.

19 The European Court of Justice's 1990 Barber ruling, discussed above, did not apply to state social security benefits, but created a political environment in which an equalisation of pension ages was more likely.

20 'Options for Equality in State Pension Age: A Case for Equalising at 65' (1992) Social Security Advisory Committee, published by HMSO, August 4th.

21 Graham Searjeant, The Times, Monday November 22nd, 1993, p. 38.

22 Patrick Wintour, The Guardian, Saturday November 22nd, 1993, p. 1.

23 Nicholas Wood, The Times, Monday November 29th, 1993, p. 1.
24 This information is from enquiries at CGU Life, Equitable Life, and the National Association of Pension Funds, an industry lobby group.

25 Missing or inadequate data mean that the questions 'Why do you save?' and 'Do you belong to an employer pension?' are not useable.

2626 people out of 5,563 reported different dates of birth in different years, which had to be corrected (see Appendix B).

27 The full question was 'Do you save any amount of your income for example by putting something away now and then in a bank, building society or Post Office account other than to meet regular bills? Please include share purchase schemes and personal equity plan schemes'.

28 Very few people were interviewed in December 1993, after the announcement.

29 The tables reporting these regressions are available from the author on request.

30 Tax-Exempt Special Savings Accounts (TESSAs) were bank or building society deposit accounts to which savers could contribute from January 1991 to April 1999. Interest earned on TESSA contributions was free from taxation, subject to a minimum holding period and maximum contribution level.

31 The BHPS file XWAVEID includes 'Interview Status' variables, but this algorithm is superior to using them, since they do not pick up whether all questions were answered.

32 Person ID No. 11105119 declared herself born in 1963 in 1991 but in 1953 thereafter.

\section{Bibliography}

Banks, J. and Tanner, S. (1996) 'Savings and Wealth in the UK: Evidence from Micro-Data', Fiscal Studies, Vol. 17, No. 2

Central Statistical Office, Family Expenditure Survey, 1992 (computer file). Colchester, Essex: The Data Archive (distributor), 20th August, 1993. SN: 3064.

Central Statistical Office, Family Expenditure Survey, 1993-1994 (computer file). Colchester, Essex: The Data Archive (distributor), 9th February, 1995. SN: 3280.

Central Statistical Office, Family Expenditure Survey, 1994-1995 (computer file). Colchester, Essex: The Data Archive (distributor), 25th April, 1996. SN: 3478.

Central Statistical Office, Family Expenditure Survey, 1995-1996 (computer file). 2nd ed. Colchester, Essex: The Data Archive (distributor), 12th December, 1997. SN: 3635.

Department of Social Security, Departmental Report, 1999, on the Internet at www.dss.gov.uk/hq/ dssreport/index.htm.

Department of Social Security, Paper No. 2, 'The Changing Welfare State: Pensioner Incomes', March 2000 , on the Internet at www.dss.gov.uk/hq/pubs/ penincomes/main/index.htm.

Department of Social Security, (1999) 'Social Security Statistics', Albert Gait Ltd. 
Economic and Social Research Council Research Centre on Micro-Social Change, British Household Panel Survey (computer file). Colchester, Essex: The Data Archive (distributor), 31st January, 2000. SN: 4069.

Luckhaus, L. and Moffat, G. (1996) 'Serving the Market and People's Needs? The Impact of European Law on Pensions in the UK', Joseph Rowntree Foundation.

Office for National Statistics, Family Expenditure Survey, 1996-1997 (computer file). Colchester, Essex: The Data Archive (distributor), 19th August, 1998. SN: 3783.

Office for National Statistics, Family Expenditure Survey, 1997-1998 (computer file). Colchester, Essex: The Data Archive (distributor), 12th March, 1999. SN: 3963.

Office for National Statistics, Family Expenditure Survey, 1998-1999 (computer file). Colchester, Essex: The Data Archive (distributor), 13th March, 2000. SN: 4071.
Office for National Statistics, (1999) 'Family Spending: A Report on the 1998-9 Family Expenditure Survey', HMSO.

Office for National Statistics, Living in Britain: Results from the General Household Survey,

volumes for the 1988 to 1998 surveys, published by HMSO, 1990-1998.

Office for National Statistics, Social Trends (29), 1999 edition, HMSO 1999.

Poterba, Jim, (1994) editor, 'International Comparisons of Household Saving', published for the NBER by the University of Chicago Press.

Taylor, Marcia Freed (ed), with John Brice, Nick Buck and Elaine Prentice-Laine (1999) 'British Household Panel Survey User Manual Volume A: Introduction, Technical Report and Appendices', University of Essex, Colchester.

Taylor, Marcia Freed (ed), with John Brice, Nick Buck and Elaine Prentice-Laine (1999) 'British Household Panel Survey User Manual Volume B: Codebook', University of Essex, Colchester. 